\title{
Plasma Lipoprotein Lipase and Hepatic Lipase Activities in Friedreich's Ataxia
}

\author{
D. BLACHE, D. BOUTHILLIER, A. BARBEAU, J. DAVIGNON
}

SUMMARY: Plasma triglycerides although within the normal range have been shown to be higher in Friedreich's ataxia than in control subjects. To determine whether this difference could be ascribed to a reduced catabolism of triglyceride-rich lipoproteins, the activities of lipoprotein lipase ( $L P L)$ and hepatic triglyceride lipase (HL), released into plasma after an heparin injection, were measured in 13 cases of Friedreich's ataxia

RÉSUMÉ: Bien que demeurant dans les limites de la normale, les triglycérides sont en moyenne plus élevés dans les cas d'ataxie de Friedreich que chez des sujets témoins. Afin de vérifier si cette différence peut être attribuable à une diminution $d u$ catabolisme des lipoprotéines riches en triglycérides, nous avons mesuré l'activité post-héparinique de la lipase lipoprotéique ( $L P L)$ et de la triglycéride lipase hépatique (HL) chez 13 patients atteints d'ataxie de Friedreich et 14 contrôles appariés pour l'âge. La LPL était significativement plus and 14 control subjects of comparable signs. LPL was found to be significantly lower in the ataxic patients. Moreover about half of the cases clustered below the normal range for both lipase activities. This subgroup of Friedreich's patients had significantly higher plasma triglycerides than those with normal lipase activities. Further studies are needed to relate these findings to other characteristics of the disease.

basse dans les cas d'ataxie. De plus, dans la moitié des cas environ, on retrouvait une diminution de l'activité des deux lipases dont les valeurs se regroupaient nettement au-dessous des valeurs extrêmes du groupe témoin. Ce sous-groupe d'ataxiques avait des triglycérides plus élevés que les autres patients dont les activités lipasiques étaient normales. Il y aurait lieu de déterminer si ces différences sont en relation avec d'autres caractéristiques cliniques ou biologiques de la maladie.
From the Department of Lipid Metabolism and Atherosclerosis Research and the Department of Neurobiology, Clinical Research Institute of Montreal.

Reprint requests for the entire supplement on Friedreich's Ataxia (Phase Three, Part Two) to: Prof André Barbeau, Clinical Research Institute of Montreal, 110 West Pine Avenue, Montreal, Quebec. Canada. H2W IR7.
We have previously observed that plasma triglycerides concentrations are higher in patients with Friedreich's ataxia than in age- and sex-matched control subjects, but usually remain within the normal range (Huang et al, 1978). This excess triglyceride is carried by the very low density lipoproteins (VLDL) and may reflect either an increased influx into plasma or a decreased removal. Triglyceride-rich lipoproteins are normally catabolized at the capillary endothelial surface in extra hepatic tissues by lipoprotein lipase (Augustin and Greten, 1979). Although its role is less well defined, hepatic triglyceride lipase (HL), another heparin-releasable enzyme, also contributes to the clearance of VLDL-triglycerides from plasma (Nicoll and Lewis, 1980; Grosser et al, 1981). To determine whether a deficiency in either of these enzyme activities could account for the higher plasma triglycerides in Friedreich's ataxia, we have measured LPL and HL released into plasma after an intravenous injection of heparin in 13 cases of Friedreich's ataxia and 14 control subjects of comparable age.

\section{SUBJECTS AND METHODS Subjects:}

The study was carried out on 13 patients affected with Friedreich's ataxia as defined by the criteria of the QCSFA (Barbeau, 1976) between the ages of 13 and 30 y (12 women, 1 man). They were compared with 14 healthy female volunteers of comparable age (range: 19 to $35 \mathrm{y}$ ) free of any neurological impairment. None of the 27 subjects had fasting hyperglycemia. One control and five patients had slightly elevated serum total bilirubin levels (i.e. greater than 
$1.2 \mathrm{mg} / \mathrm{dl})$. One control and one patient had fasting plasma triglycerides greater than $150 \mathrm{mg} / \mathrm{dl}$. The means and standard deviations for these parameters in each group are given in the table. They were compared by a standard unpaired Student's t test.

\section{Methods:}

Blood was obtained in the morning from an antecubital vein after a 12 hour fast for lipid, glucose and bilirubin measurements. Heparin, 10 units per $\mathrm{kg}$ of body weight, was injected intravenously and exactly 10 minutes later another blood sample was drawn from a vein in the opposite arm for LPL and HL determination.

Plasma cholesterol (Allain et al, 1974) and triglycerides (Sampson et al, 1975) were measured by enzymatic methods on an ABA-100 bichromatic analyzer (Abbott Laboratories). Serum glucose and bilirubin were measured in the routine clinical laboratory of the Hôtel-Dieu Hospital on a Technicon SMAC autoanalyzer.

Lipoprotein lipase and hepatic triglyceride lipase were measured according to a modified technique developed recently in our laboratory (Blache et al, 1980). With this method the post-heparin plasma is incubated in a Tris- $\mathrm{HCl}$ buffer containing bovine serum albumin in the presence of tri(1${ }^{14} \mathrm{C}$ ) oleoyl-glycerol emulsified by sonication with $5 \%$ gum arabic as substrate. The reaction is topped by addition of a benzene-chloroform-methanol mixture and $\mathrm{NaOH} 0.2 \mathrm{M}$. Labelled oleic acid is extracted with hexane. The pooled extracts are evaporated and redissolved in Aquasol-2 (New England Nuclear) for counting. The assay for LPL is carried out after preincubation with an antiserum specific to hepatic triglyceride lipase at $\mathrm{pH} 8.4$ in the presence of bovine serum albumin, $0.15 \mathrm{M} \mathrm{NaCl}$ and $11 \%$ pooled human normal plasma as a source of the activator apolipoprotein C-II. The assay conditions for HL exclude the preincubation and no activator is added. It is carried out at $\mathrm{pH} 8.9$ in the presence of $0.1 \mathrm{M} \mathrm{NaCl}$ to inhibit LPL activity. Results are expressed in $\mathrm{U} / \mathrm{ml}$ of postheparin plasma where 1 unit represents 1 umole of fatty acid released per hour.
All lipase measurements were done in triplicate.

\section{RESULTS}

As shown in the table, there were no differences between the two groups as far as age, fasting serum glucose and plasma cholesterol concentrations are concerned. Serum bilirubin levels were significantly higher in the Friedreich's patients because of the 5 hyperbilirubinemic subjects. Plasma triglycerides were higher in the patients but the difference did not reach statistical significance because of the wide variation in this group. Plasma LPL activity was significantly lower in the group of patients with Friedreich's ataxia whereas no differences were observed between the two groups for plasma HL.

Interestingly about half of the cases of Friedreich's ataxia had levels of LPL and HL below the ranges observed for normal values. For LPL the normal range extended from 5.02 to 10.94 and for HL from 3.12 to 8.1 . Six patients had values of LPL below 5 ranging from as low as 0.89 to 4.63 and $7 \mathrm{had}$ HL activities between 1.61 and 2.98.

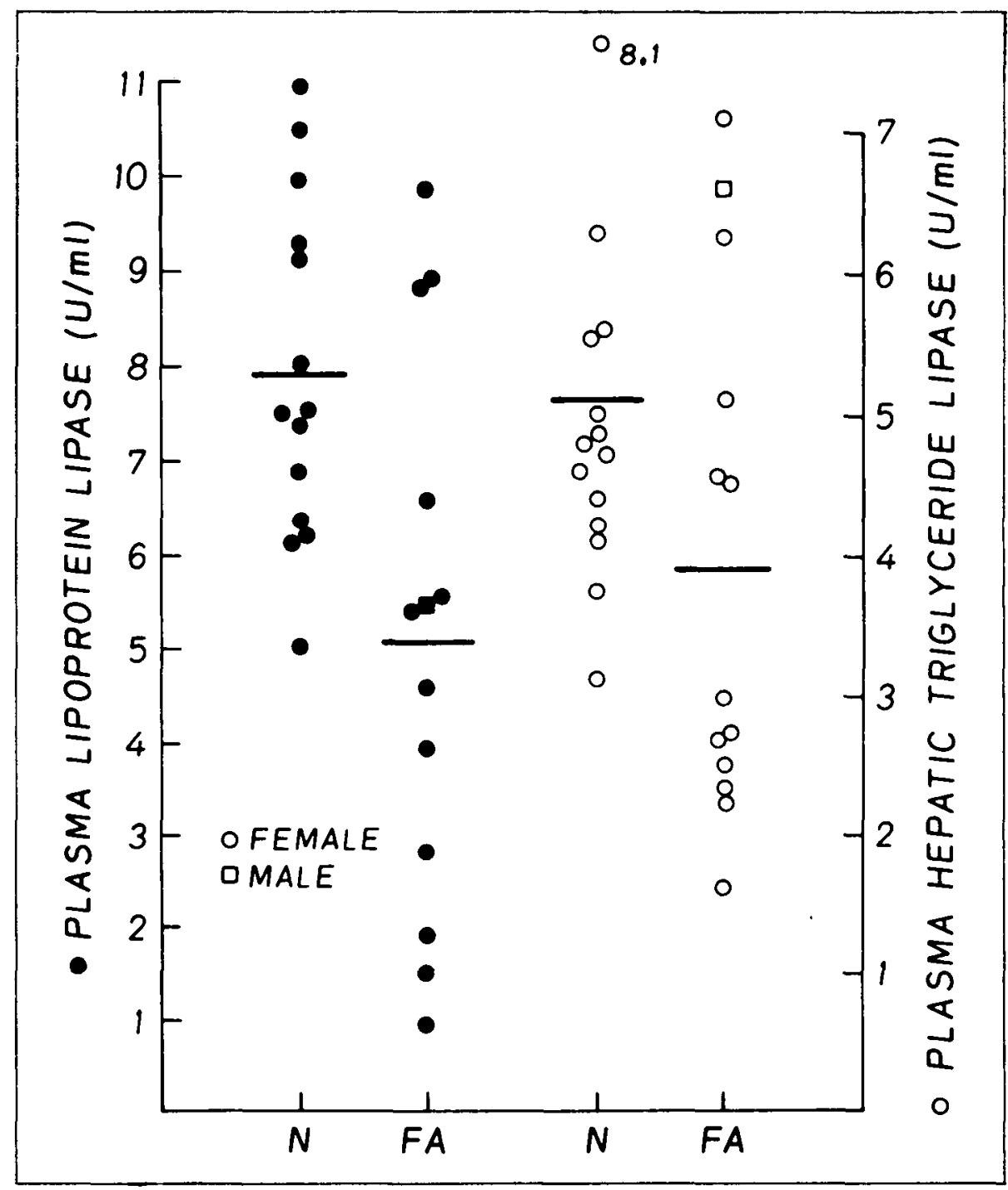

Figure 1 - Plasma post-heparin lipase activities in normal controls $(\mathrm{N})$ and in Friedreich's ataxia patients (FA). The figure demonstrates the dispersion of the individual values and the clustering of $\mathrm{HL}$ activities (open circles) in 7 patients below the lowest level observed in the controls. Six of these 7 cases also have LPL activities (black dots) below the range of normal and the 7th has the lowest level among those in the normal range. This subgroup of ataxic patients have significantly higher plasma triglycerides than the others. 


\section{TABLE I}

Plasma post-heparin lipases in Friedreich's ataxia

\begin{tabular}{|c|c|c|c|}
\hline & Controls & Friedreich & $\mathrm{p}$ \\
\hline Number of subjects (males) & $14(0)$ & $13(1)$ & \\
\hline Age, years & $25.6 \pm 5.9 *$ & $23.1 \pm 5.6$ & NS \\
\hline Glycemia, $\mathrm{mg} / \mathrm{dl}$ & $85 . \pm 8.7$ & $92 \pm 7.7$ & NS \\
\hline Total serum bilirubin, mg/dl & $0.6 \pm 0.07$ & $1.12 \pm 0.7 \star \star$ & $<0.02$ \\
\hline Plasma cholesterol, $\mathrm{mg} / \mathrm{dl}$ & $178 \pm 32$ & $180 \pm 33$ & NS \\
\hline Plasma triglycerides, $\mathrm{mg} / \mathrm{dl}$ & $79 \pm 41$ & $111 \pm 92$ & NS \\
\hline Lipoprotein lipase, $\mathrm{U} / \mathrm{ml}$ & $7.9 \pm 1.8$ & $5.1 \pm 2.9$ & $<0.01$ \\
\hline Hepatic lipase, $\mathrm{U} / \mathrm{ml}$ & $4.9 \pm 1.2$ & $4.0 \pm 1.9$ & NS \\
\hline $\begin{array}{l}\star \text { mean } \pm \text { SO } \\
\star \star 5 \text { hyperbilirubinemic subj }\end{array}$ & & & \\
\hline
\end{tabular}

This is well illustrated in the figure where a clustering of $\mathrm{HL}$ in the low range is quite apparent for a group of patients with Friedreich's ataxia. All six patients with low LPL also had low HL. The other one with low HL had a LPL activity of only 5.36 and was the sister of another patient with both low HL and LPL. The low values were unrelated to hyperbilirubinemia but definitely related to higher plasma triglyceride levels. Indeed the low HL cases had a mean concentration of plasma triglycerides \pm SD of $148 \pm$ $114 \mathrm{mg} / \mathrm{dl}$ as compared to $68 \pm 21$ $\mathrm{mg} / \mathrm{dl}$ for the other 6 patients. This difference was still present after exclusion of one outlier who had $400 \mathrm{mg} / \mathrm{dl}$ of plasma triglycerides: $106 \pm 28$ vs 68 $\pm 21 \mathrm{mg} / \mathrm{dl}(\mathrm{p}<0.025)$

\section{DISCUSSION}

The results obtained indicate that the higher plasma triglyceride levels observed in Friedreich's ataxia are secondary to a reduction in plasma lipoprotein lipase activity. This was to be expected since in conditions where plasma triglycerides are elevated because of a deficiency in this enzyme, such as in familial hyperchylomicronemia (Fredrickson et al, 1978), plasma high density lipoproteins are concurrently decreased as in Fried- reich's ataxia (Huang et al, 1978). Furthermore an effective catabolism of VLDL usually results in an increase in HDL especially in $\mathrm{HDL}_{2}$ fraction which is enriched in cholesterol esters (Nikkila 1978), a situation opposite to that observed in Friedreich's ataxia where HDL concentrations are lowered and the particles enriched in triglycerides and free cholesterol (Huang et al, 1978, Davignon et al, 1979).

Of major interest is the finding that a subgroup of Friedreich's ataxia patients clustered in the low range for both heparin-releasable lipase activities. This indicates the presence of metabolic heterogeneity which could account for the wide ranges observed at times not only for triglyceride levels but also for plasma HDL concentrations. Thus the higher triglycerides in Friedreich's ataxia on the average could be ascribed to a subpopulation of patients having low levels of both LPL and $\mathrm{HL}$ and a reduced catabolism of very low density lipoproteins. Further studies are needed to relate these metabolic differences to other disease characteristics of Friedreich's ataxia. This difference does not appear to be related to the presence of hyperbilirubinemia, since there were 2 patients with hyperbilirubinemia in the low lipase group and 3 among those with normal lipase. Neither can it be ascribed to differences in the stage of the disease since both subgroups were comparable from that standpoint. There were 4 pairs of siblings among the Friedreich's cases; related individuals had similar levels of lipase activities and belonged to the same subgroup. It would be important to determine if the previously described abnormalities in HDL concentration and composition (Huang et al, 1978, Davignon et al, 1979) are more closely associated with patients of the low lipase subgroup. Indeed it has been shown recently that a deficiency in $\mathrm{HL}$ in man induces an increase in the proportion of triglyceride and phosphatidylcholine and a decrease in the free cholesterol content of $\mathrm{HDL}$ (Breckenridge C.W. personal communication). Finally the reason for a decrease in both enzyme activities in some patients remains to be determined and the presence of a circulating inhibitor cannot be excluded.

\section{ACKNOWLEDGEMENTS}

This work was supported by the Association Canadienne de l'Ataxie de Friedreich, the Medical Research Council of Canada and the Quebec Heart Foundation. The authors wish to thank Mr. Michel Tremblay for his technical assistance and Miss Danielle Bedard, R.N., for help with the patients.

\section{REFERENCES}

ALLAIN, C.C., POON, L.S., CHAN, F.C.S., RICHMOND, W. and FU, P.C. (1974). Enzymatic determination of total serum cholesterol. Clin. Chem. 20, 470-475.

AUGUSTIN, J. and GRETEN, H. (1979). The role of lipoprotein lipase-molecular properties and clinical relevance. Atheroscler. Rev. 5,91-124.

BARBEAU, A. (1976). Friedreich's ataxia 1976. An overview. Can. J. Neurol. Sci. 3, 389-397.

BLACHE, D., HUANG, Y.S. and DAVIGNON, J. (1980). A modified simple and reproducible procedure for the measurement of plasma post-heparin lipase activities. Clin. Chem. 26, 1048.

DAVIGNON, J., HUANG, Y.S., WOLF, J.P. and BARBEAU, A. (1979). Fatty acid profile of major lipid classes in plasma lipoproteins of patients with Friedreich's Ataxia - Demonstration of a low linoleic acid content most evident in the cholesterylester fraction. Can. J. Neurol. Sci. 6, 275 283. 
FREDRICKSON, D.S., GOLDSTEIN, J.L. and BROWN, M.S. (1978). The familial hyperlipoproteinemias. In: The Metabolic Basis of Inherited Disease, 4 th edition. Stanbury, J.B., Wyngaarden, J.N. and Fredrickson, D.S. (eds). McGraw Hill, New York, pp. 604-655.

GROSSER, J., SCHRECKER, O. and GRETEN, H. (1981). Function of hepatic triglyceride lipase in lipoprotein metabolism. J. Lipid Res. 22, 437-442.
HUANG, Y.S., NESTRUCK, A.C., BARBEAU, A., BOUCHARD, J.P. and DAVIGNON, J. (1978). Plasma lipids and lipoproteins in Friedreich's Ataxia and Familial Spastic Ataxia - evidence for an abnormal composition of high density lipoproteins. Can. J. Neurol. Sci. 5, 149-156.

NICOLL, A. and LEWIS, B. (1980). Evaluation of the roles of lipoprotein lipase and hepatic lipase in lipoprotein metabolism - in vivo and in vitro studies in man. Eur. J. Clin. Invest. 10, 487-495.
NIKKILA, E.A. (1978). Metabolic and endocrine control of plasma high density lipoprotein concentration. In: High density lipoproteins and atherosclerosis. Gotto. A.M. Miller, N.E. and Oliver, M.F. (eds). Elsevier, Amsterdam, pp. 177-192.

SAMPSON, E.J., DEMERS, L.M. and KRIEG, A.F. (1975). Faster enzymatic procedure for serum triglycerides. Clin. Chem. 21, 1983-1985. 